
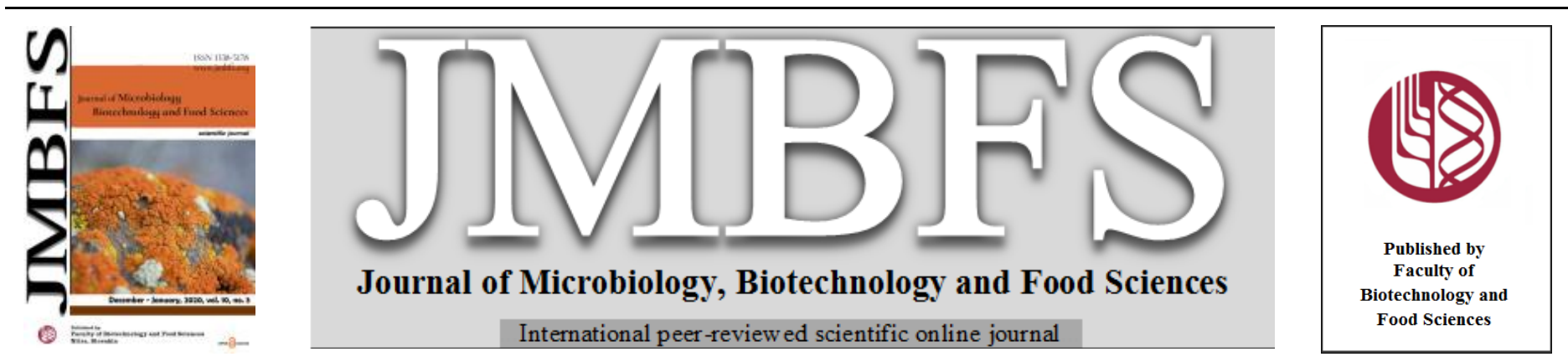

\title{
INCIDENCE AND CONTROL OF INFECTIOUS BACTERIA IN BOVINE MILK
}

\author{
Doaa Sedky ${ }^{*}$, Alaa A. Ghazy , Khloud A. Soliman ${ }^{2}$ \\ Address(es): Doaa Sedky, PhD., \\ ${ }^{1}$ National Research Centre, Parasitology and Animal Diseases Department, Veterinary Research Division, Postal code: 12622, Dokki, Cairo, Egypt. \\ ${ }^{2}$ Cairo University, Faculty of Medicine, El Kasr El Aini, Postal code: 11562 Cairo, Egypt.
}

*Corresponding author: doaa_sedky@yahoo.com

doi: $10.15414 / j m b f s .2020 .10 .3 .398-404$

\section{ARTICLE INFO}

Received 31. 5. 2019

Revised 18. 7. 2020

Accepted 10. 8. 2020

Published 1. 12. 2020

\section{Review}

OPEN $\partial_{\text {ACCESS }}$

\begin{abstract}
Milk is an essential source for the ingredients needed for infant growth and adult health. Healthy milk production is important for consumer safety. The aim of the present review article was to highlight on the incidence and control of the infectious bacteria in bovine milk. Raw bovine milk is considered as a vehicle for many infectious bacterial diseases such as Bovine Tuberculosis, Brucellosis, Leptospirosis and Mycoplasma infection. The main microorganisms which isolated from bovine milk in cows with mastitis were Escherichia coli, Staphylococcus aureus, Streptococcus spp., Streptococcus agalactiae, Pasteurella spp., Klebsiella spp., Pseudomonas spp. and Streptococcus dysgalactiae. Early and accurate diagnosis is necessary for achieving successful control programs against the infectious bacteria in bovine milk. For successful control of the infectious bacterial diseases in bovine milk, it is mandatory to follow preventive measures such as proper hygienic procedures regarding animal husbandry and handling, providing the cows with balanced nutrition, following vaccination programs against bacterial diseases, reporting of the notifiable diseases to the health authorities, meticulous inspection of the consistency and color of milk and pasteurization of milk. Vaccination programs provide protection of dairy farm animals by preventing or reducing bacterial infections which in turn can help safeguard dairy industry. The main treatment protocol of bacterial diseases in dairy cows is by using suitable antibiotics, so it is necessary to carry out drug sensitivity test before choosing the proper antibiotic. However, multidrug resistance (MDR) has become a growing threat regards the management of infectious bacterial diseases. Therefore, the introduction of alternative antimicrobial agents such as herbal treatment, probiotics, nanoparticles, and stem cells therapy is of absolute necessity to guard against bacterial multidrug resistance. Also, animal vaccinations are important tools for protection against many infectious bacterial diseases affecting bovine milk.
\end{abstract}

Keywords: bovine milk, mastitis, infectious bacteria, incidence, control

\section{INTRODUCTION}

Dairy cattle caught to be maintained in ideal physical condition in a commercial milking environment in order to sustain a high level of milk production. Thus, the possibility of developing infections in modern dairy farms has increased. Low milk production has been linked to the disease control in dairy cattle; furthermore, mastitis is recognized as the most important cause for economic losses on dairy farms in many countries in the world (Petroviski et al., 2006). Milk and other dairy products are often infected with S. aureus. Milk of infected animals is the main source of enterotoxigenic Staphylococcus aureus of animal origin. Some of the strains of $S$. aureus produce heat-resistant enterotoxins (toxins cannot be destroyed by heating or drying), which cause nausea, vomiting and abdominal cramps when ingested by humans and are responsible for outbreaks of food poisoning caused by S. aureus (Gilmour and Harvey, 1997). Mastitis has been ranked as the first disease of dairy animals as recorded by many field surveys which performed to investigate the major livestock diseases. Mastitis causes severe economic losses in dairy farms and consequently influencing the dairy industry (Ismail, 2017). Ameliorating udder health, with the aim of decreasing the incidence of udder infection and inflammation in dairy herds, will eventually lead to increasing milk production. Treatment periods, culling of cows and death of clinically infected cattle resulted in massive loss of milk production in dairy farms. Reduction of mastitis occurrence by application of the different control programs, using different methods in dairy farming as animal husbandry, feeding and general hygienic methods, will help in decreasing the incidence of udder infections. Implementing of good farming practices together with the using of antimicrobials for treating of infection could possibly aid in the decreasing or abolishing of the incidence of mastitis in dairy farms (Petroviski et al., 2006). The somatic cell count (SCC) is the key indicator for evaluation of the quality of the milk. White blood cells constitute the majority of SCC $(75 \%)$, while epithelia represent $25 \%$. The number of SCC increases with the increase of immune response as in cases of infection with pathogenic bacteria
(Harmon, 1994). The somatic cell count in normal milk is usually less than 100,000 cells $/ \mathrm{ml}$. Meanwhile in case of bacterial infections, the SCC will increase to reach levels greater than 100,000 cells/ $\mathrm{ml}$ (Bytyqi et al., 2010). The most predominant bacteria identified in bovine milk from mastitic cow were Streptococci (48 \%), S. aureus (29\%), E. coli (36\%) and coagulase-negative staphylococci $(11 \%)$ (Hussein et al., 2018). Mastitis mostly arises from udder injury and subsequent invasion of bacteria. Moreover, rapid and prompt treatment will significantly decrease the chances of developing mastitis in case of accidental udder injury as bacteria invade through injury (Kumar $\boldsymbol{e t}$ al., 2010). Many publications have recommended the administration of antibiotic therapy during the dry period for controlling of intramammary infections and prevention of mastitis (Janosi and Huszenicza, 2001; Kashif $\boldsymbol{e} t$ al., 2016). It has been showed that administration of therapy during the dry period can eradicate up to $70 \%$ of the environmental streptococcal infections. The basic methods for controlling of mastitis are either by reducing the teat exposure to potential pathogens or by enhancing the dairy animal's resistance to infection. Multidrug resistance (MDR) has become an arising threat in the treatment of infectious bacterial diseases; this problem is assigned to the hazard use of broadspectrum antibiotics (Saini et al., 2012; Hakim et al., 2017), which results in massive economic losses in dairy farming. Therefore, it is crucial to create novel antimicrobial agents such as nanoparticles which provide means to overcome MDR. Medicinal plants have many advantages as they are natural, safe, effective and economical alternative treatment for mastitis (Schmidt Lebuhn, 2008) Many reports showed that the drug sensitivity patterns may vary greatly according to geographical regions and animal species. The use of two nisins viz. Ambicin (nisin A) have germicidal activities against S. aureus, S. agalactiae, $S$. uberis, K. pneumoniae and E. coli, and nisin $\mathrm{Z}$ are widely accepted. It has been showed that the new bacteriocin, which is produced by Lactococcus lactis spp. lactis DPC3147, is effective against a wide range of Gram positive bacteria Furthermore, lactin NK34 (partially purified from lacticin NK34) has in vivo preventive and therapeutic effects against mastitis pathogens (Espeche $\boldsymbol{e t}$ al., 
2009; Bogni et al., 2011). Prenafeta et al. (2010) reported that the immunization of twelve gestating dairy cows with a vaccine consists of extracellular component from $S$. aureus leads to a marked decrease in $S$. aureus growth in the mammary gland. There are many diseases prevented by pasteurization including tuberculosis, brucellosis, Salmonella, Listeria, Yersinia, Campylobacter, S. aureus, $Q$ fever and E. coli O157:H7.21,22. On the other hand, Ultra pasteurization is a food processing method that aims to sterilize milk by heating it above $135{ }^{\circ} \mathrm{C}$ for one to two seconds which is necessary to destroy spores (LeJeune and Schultz, 2009). The management of mastaitis depends mainly on meticulous regular monitoring with routine physical examination of the udder and checking the milk quality. Furthermore, by regular using of disinfectants and vaccines in endemic areas. There are some vaccines in the trial guarding against bovine mastitis including inactivated highly encapsulated $S$. aureus cells; a crude extract of S. aureus exopolysaccharides; S. aureus CP5 whole cell vaccine inactivated and unencapsulated $S$. aureus as well as Streptococcus spp. cells based vaccine developed for controlling of bovine mastitis (Calzolari et al., 1997; Camussone et al., 2013); recombinant staphylococcal enterotoxin type $C$ mutant vaccine (Chang et al., 2008); recombinant Streptococcus uberis GapC or a chimeric Christie Atkins Munch-Petersen (CAMP) antigen; pauA; live Strep. uberis 0140J stain and bacterial surface extract (Finch $\boldsymbol{e t}$ al., 1997; Fontaine $\boldsymbol{e} t$ al., 2002); DNA vaccine containing clumping factor $\mathrm{A}$ of $S$. aureus and bovine IL 18 (Yin et al., 2009) and DNA- Protein vaccine against S. aureus (Shkreta $\boldsymbol{e}$ al., 2004). There are many available conventional and modern techniques used for the diagnosis of infectious bacteria in bovine milk. For successful control of the infectious bacterial diseases in bovine milk, it is mandatory to follow preventive measures, following vaccination program and treatment of diseased animals. A variety of treatment and prevention protocols have been developed over the years with variable successive rates to the problem. Therefore, the purpose of the present study is to investigate the incidence and control of the infectious bacteria in bovine milk.

\section{Incidence of infectious bacteria in bovine milk in Egypt}

\section{Incidence of Mycobacterium tuberculosis}

The incidence of cases with Mycobacterium tuberculosis in 46 suspected cattle kept in a private farm at Egypt was estimated. Examination of Mycobacterial culture revealed that $4.35 \%$ of the collected bovine milk samples were positive for Mycobacterium bovis isolation (Hassanain et al., 2009). In a study at Giza province, Mycobacterium bovis was isolated from milk samples of 19 out of 50 examined dairy cattle (38.0\%), which exposed to bovine tuberculosis outbreak, using Lowenstein-Jensen medium (Ghazy et al, 2007b). In another study, a total number of 1850 of cattle from different farms in Egypt were examined for bovine tuberculosis by tuberculin intradermal test using mammalian purified protein derivative. A total of 36/1850 (1.90\%) were positive reactors by single cervical test (Mosaad et al., 2012).

\section{Incidence of Mycoplasma}

The incidence of Mycoplasma in raw milk of different lactating animal species was estimated. A total of 240 random raw milk samples were collected from cows, buffaloes, sheep and goats in Assiut and Qena cities, Egypt. Fifteen strains of Mycoplasma were isolated and identified from raw milk (Saad and AbdelHameed, 2012). In another study, a total of 80 milk samples were collected from Mycoplasma infected bovine farm which tested by conventional cultural method and indirect Enzyme Linked Immunosorbant Assay (ELISA). Twenty four milk samples revealed positive culture (30\%), while $33(41.25 \%)$ of the milk samples revealed positive by ELISA titer to Mycoplasma bovis (Abdelhafez et al., 2009). Milk samples from 625 cows and buffaloes suffering from clinical and subclinical mastitis in two Egyptian provinces (Fayoum and Dakahlia provinces) were examined. Mycoplasma infection was reported to be higher in cows than buffaloes in both governorates in the clinical mastitic cases. While in subclinical mastitic cases, the infection were $30.19 \%$ and $38.3 \%$ in Dakahlia Governorate and $20.6 \%$ and $12 \%$ in Fayoum Governorate for cows and buffaloes, respectively (Eissa et al., 2012).

Incidence of Brucella

Brucella species were detected by real-time PCR in bovine milk and milk products collected from apparently healthy animals in Egypt. Antibodies against Brucella spp. were reported in 34 samples (16\%); while Brucella spp. was recorded in 17 milk samples (7.9\%) using RT-PCR amplified Brucella-specific DNA. Species-specific IS711 RT-PCR revealed that 16 samples from the RTPCR-positive samples were identified as B. melitensis; meanwhile one RT-PCRpositive sample was identified as B. abortus (Wareth et al., 2014). A total number of 84 female dairy buffaloes at Giza province, Egypt were examined for brucellosis. Serological examination revealed prevalence level of $11.9 \%$ using Rose Bengal Plate Test. Brucella melitensis biovar-3 was isolated from tissue samples obtained from brucella positive seroreactive buffaloes during obligatory slaughtering (Ghazy et al., 2007b).

Incidence of other infectious bacteria in bovine milk

Differences in bacterial mastitic infections prevalence rates between farms are reported. About $95 \%$ of all infections are caused by Streptococcus agalactiae, Staphylococcus aureus, Streptococcus dysgalactiae, Streptococcus uberis and E. coli (Gilmour and Harvey, 1997). The common pathogenic microorganisms that detected in mastitic cows from different farms at Ismailia province were Staphylococcus aureus (32.3\%), Streptococcus uberis (13\%), Staphylococcus epidermidis (12\%), E. coli (10.2\%), Streptococcus dysgalactiae (10\%), Streptococcus bovis (6.2\%), Klebsiella pneumoniae (3.4\%), Enterococcus fecalis (3.1\%), Enterococcus faecium (1.5\%) and Proteus vulgaris (1.4\%) (Enany et al., 2007). Nine small-scale dairy farms include 982 animals

(565 Friesian cows and 417 buffaloes) at Kaluobia and Menofia provinces were clinically inspected for detection of udder and/or milk abnormalities. Mycoplasma is occupied a considerable level of the isolates from the clinically mastitic cases (19.70\%), and it is occupied the second grade (28.57\%) following Staphylococcus aureus $(42.86 \%$ ) as etiologic agent responsible for incurable mastitis of cows (AbdelHameed and Sharaf, 2009).

Ghazy et al. (2007a) reported that out of 360 female dairy buffaloes examined in Lower Egypt, 5.8\% were positive to mastitis. The incidence of mastitis in a private dairy herd in Beni-suef province was also estimated. Two hundreds and seventy two bacteria were isolated; the most predominant infectious bacteria were coagulase negative Staphylococcus $(37 \%)$, Staphylococcus aureus $(25 \%)$ and E.coli (18\%). Other bacterial isolates incorporated were Streptcoccus agalactiae (11\%), Klebsiella pneumonae (3\%) and Streptococcus uberis $(2 \%)$ (Elbably et al., 2013). The prevalence of the cases with clinical mastitis, subclinical mastitis and apparently healthy dairy cows recorded $34.5 \%, 24.7 \%$ and $40.8 \%$, respectively. The most important pathogens which detected from the examined milk samples were Escherichia coli (22.16\%), S. aureus (20.19\%), Streptococcus spp. (13.3\%), Streptococcus agalactiae (12.8\%), Pasteurella spp. (2.45\%), Klebsiella spp. (1.47\%), Pseudomonas spp. (0.45\%) and Streptococcus dysgalactiae $(0.5 \%)$ (Zeedan et al., 2014). One hundred and twelve bovine milk samples were examined by California mastitis test (CMT) and Somatic cells count (SCC). 56.3\% was the percentage of subclinical mastitis and $13.3 \%$ was the percentage of clinical mastitis. Bacteriological culture of bacterial agents causing mastitis on different types of media revealed that the causative agents were E. coli $(25.5 \%)$, Staphylococcus aureus (14.8\%), Coagulase negative Staphylococcus (12.7\%), Streptococcus agalactiae (12.7\%), Streptococcus pyogens (10.6\%), Klebsiella pneumoniae (8.5\%), Salmonella species $(4.2 \%)$, Proteus species (4.2\%) and Pseudomonas aerguinosa (4.2\%) (Sayed et al., 2014).

The incidence of $E$. coli in cows and buffaloes were studied. E.coli was higher in cows (31 isolates, $21.1 \%)$ than in buffaloes ( 8 isolates, $18.3 \%)$. Serological typing of $E$. coli showed that O55 was 30\%, followed by O111 and O124 (15\%), $\mathrm{O} 119, \mathrm{O} 114$ and $\mathrm{O} 157$ (10\%), O26 and O44 (5\%). The results revealed that most serotypes causing mastitis were O55, O111 and O124 (Mahmoud et al., 2015) In some dairy farms in Beni-Suef province, a total of 20 and 78 bovine milk samples were collected from animals showing signs of clinical and subclinical mastitis, respectively. The isolated microorganisms were Staphylococcus species $(n=79 ; 80.61 \%)$, Enterococcus spp. $(\mathrm{n}=28 ; 28.57 \%)$, Pseudomonas aeruginosa $(n=7 ; 7.14 \%)$, E. coli $(n=3 ; 3.06 \%)$ and Proteus vulgaris $(n=1 ; 1.02 \%)$ (Hassan et al., 2016). Examinations of 270 milk samples from cows in Dakahlia, Sharkia and Damieta provinces revealed that 200 were mastitic cows and 70 were apparently healthy. Bacteriological examination revealed high percentage of Pseudomonas aeruginosa isolates in Damietta province $(8.1 \%)$, followed by Sharkia province (7.6\%) and Dakhlia province (6.9\%) (Ammar et al., 2016).

The prevalence of Clostridium perfringens in the bovine milk of the clinical and subclinical mastitic cows was studied. Four isolates of $C$. perfringens were recovered from the cows $(3.92 \%)$ in the subclinical mastitis. While twelve isolates of $C$. perfringens (4.7\%) were isolated from clinically affected quarters (Osman et al., 2009).

Control of infectious bacteria in bovine milk General control and preventive measures

The cornerstone of controlling infectious bacterial diseases in bovine is by following proper hygienic procedures regarding animal husbandry and handling which will decrease the spread of bacterial pathogenic agents. Also, the application of disinfectants in sheds and paddocks regularly can decrease the chance of infection. Mastitis mostly arises from udder injury and subsequent invasion of microbes, so preventing udder lesions is important. Moreover, rapid and prompt treatment will significantly decrease the chances of developing mastitis in case of accidental udder injury (Kumar et al., 2010). Proper hygienic measures include cleaning of the sheds regularly, application of antiseptics on the teats after milking; thus reducing the chances of microbial invasion, enhancement of the hygiene of milking process, monitoring milking equipments regularly, prevention of galactophagia (inter-sucking) between young ones, implementation of milking order and using bedding material that doesn't favor bacterial growth (OldeRiekerink et al., 2012). Monitoring milk and milk samples on regular basis will decrease the number of infected animals. Meticulous inspection of the consistency and color of milk will increase the chances of early diagnosis. Balanced nutrition plays key role in 
prevention of infectious diseases in bovine. Vitamin E enhances the immune response of cows as it improves the neutrophils phagocytic capacity following parturition (Hogan et al., 1992a; Spears and Weiss, 2008). Previous studies showed that supplementation with selenium and vitamin E resulted in elevated resistance to bovine mastitis (Erskine et al., 1989; Underwood and Suttle, 1999). Also, selenium has anti-oxidant properties resulting in improving of the immune status and elevating the lymphocyte and phagocyte activities (Chamberlain and Wilkenson, 1996; Abou-Zeina et al., 2013).

Pasteurization is defined as a process in which milk is treated with mild heat less than $100{ }^{\circ} \mathrm{C}$ to eliminate micro-organisms and increases the shelf-life time of milk. The process is aimed to eliminate vegetative bacteria, but it doesn't destroy bacterial spores (Pearce $\boldsymbol{e t}$ al., 2012). Pasteurization aims to log reduction of the number of viable bacteria so that they are unable to cause disease. There are many diseases can be prevented by pasteurization including tuberculosis, brucellosis, Salmonella, Listeria, Yersinia, Campylobacter, Staphylococcus aureus, $Q$ fever and Escherichia coli O157:H7.21,22. On the other hand, Ultra pasteurization is a food processing technology that involves heating of milk above $135{ }^{\circ} \mathrm{C}$ for $1-2$ seconds rendering it sterilized (LeJeune and Schultz, 2009). Today, pasteurization is used broadly within the dairy industry.

Bovine tuberculosis is a notifiable disease, the government officials and veterinarians must cooperate with each others to set up a plan to eradicate the disease among the herd. Using milk replacer and colostrum supplements will eliminate the hazards of disease transmission which is an essential step in execution of any prevention and control strategy (Cousins, 2001). There is no effective treatment for brucellosis, so following control measures is fundamental step. These measures include proper diagnosis, quarantine, exclusion of the diseased cow from the herd, slaughtering and proper discarding of seropositive cows to reduce the incidence of infection in healthy animals, vaccination of calf, and utilization of semen from an examined bull free from Brucella (Bhanu Rekha et al., 2013). Hygienic practices would contribute to spread of the disease in/from endemic regions (Khan and Zahoor, 2018). Mycoplasma bovis mastitis requires very long period of time for treatment and this does not always result in disease cure. Diseased cows should be culled as early as possible out of the dairy herd to avoid the lateral transmissions of infection to the neighboring unaffected animals, and to avoid the transmission of infection to neonates and calves. Mycoplasmal examination, in the infected farm, should be performed regularly in parallel with routine detection of mastitis until elimination by segregation or cull of the infected cases (AbdelHameed and Sharaf, 2009).

\section{Treatment of diseased animals}

\section{Antibiotic treatment}

Infectious bacteria treatment relies fundamentally on trial and error. Many microorganisms contribute to development of infectious diseases in cows, so it is necessary to carry out drug sensitivity test before choosing the proper antibiotic. Researchers pointed out that drug sensitivity reports vary greatly in different animal species and geographical region (Verma et al., 2018). It is recommended to give treatments during lactation in case of clinical mastitis; on the other hand, it is not recommended to treat subclinical mastitis during lactation due to low cure rate and high cost of treatment (Halasa et al., 2007). The combination of parenteral and local intramammary antibiotic injections yields high cure rates. However, the administration of systemic therapy may be recommended when the udder parenchyma is severely congested, as the inflammatory secretion and cellular debris may obstruct the milk duct system, thus preventing the injected intramammary drug from proper distribution throughout the udder (Grueta et al., 2001). The main drugs which has been approved by the Food and Drug Administration for Veterinary Medicine (FDA, 2011) for the treatment of bovine mastitis were pirlimycin, methicillin, cloxacillin, amoxicillin, novobiocin, penicillin $\mathrm{G}$, dihydrostreptomycin, cephapirin and erythromycin. Intramammary treatment with penicillin and novobiocin was more effective against $S$. aureus (Owens et al., 1997). The administration of systemic danofloxacin for the treatment of induced acute Escherichia coli in bovine mastitis enhanced the cure rates of mastitic cows (Poutrel $\boldsymbol{e}$ al., 2008). Corynebacterium pyogenes showed $100 \%$ resistance to Penicillin G. Meanwhile, it showed high sensitivity (100\%) to Cephalexin and Gentamicin (Madut and Gadir, 2011). Treatment regimes of bovine tuberculosis with Isoniazid require daily dosing for up to 2 or 3 months. Therefore, Isoniazid cannot be regarded as a mean of eradicating of the disease (Huchzermyer $\boldsymbol{e t}$ al . 1994; Cousins, 2001). The cure rate of $S$. aureus mastitis ranges from $0 \%$ to $80 \%$, and the antibiotic resistance is attributed to many factors as the production of resistant biofilm (Grueta et al., 2001; Babra et al., 2013). The severity of the infection is indicated by SCC. Bovine animals with SCC less than 1000000 revealed the greatest success of antibiotic therapy, on the other hand, animals with higher SCC revealed a limited response (Timms, 2001). Unfortunately, some antibiotics administrated for the treatment of mastitis such as penicillin, oxytetracycline, lincomycin and neomycin may compromise the phagocytic capacity of polymorphonuclear leukocytes (PMN) by changing the oxidative burst character of PMN resulting in a recurrence of infections (Paape $\boldsymbol{e t}$ al., 2003).

\section{Antibiograms (Antibiotic sensitivity tests)}

Antibiotic sensitivity tests are specific guide for treatment that estimates the susceptibility and resistance of the obtained bacterial isolates to certain antibiotics to be applied during therapy. The drug of choice should have the biggest inhibition zone around inserted disc. Their main disadvantages are being not effective against resistant strain (Quinn et al., 2013). Multidrug resistance bacteria were isolated from bovine mastitic cases as follows; Enterobacter cloacae $(7.1 \%), K$. pneumoniae $(6.3 \%), K$. oxytoca $(6.3 \%)$, E. coli $(4.5 \%)$, and Citrobacter freundii (2.7\%). The most commonly observed resistance phenotypes were against ampicillin $(97.0 \%)$, streptomycin $(94.1 \%)$, tetracycline $(91.2 \%)$, trimethoprim- sulfamethoxazole $(88.2 \%)$, nalidixic acid $(85.3 \%)$, and chloramphenicol (76.5\%) (Ahmed and Shimamoto, 2011).

\section{Dry cow therapy}

Many publications recommended the administration of antibiotic therapy during the dry period for controlling intramammary infection and prevention of mastitis (Janosi and Huszenicza, 2001; Kashif et al., 2016). Cows are susceptible to acquire new infections with both Gram-positive and Gram-negative bacteria during the dry period (Berry and Hillerton, 2002). The main advantage of the dry cow therapy is that it enables the treatment of bacteria and it eliminates the need of discarding the milk. Moreover, the antibiotics which remain in the udder up to 20-70 days at high concentration sufficient to kill infectious bacteria, and this depends on the type of antibiotic formulations used. Also, the prolonged exposure time to antibiotics hastens the curing rates of intramammary bacterial diseases. However, this can be hindered in case of biofilm formation by the invading pathogens (Babra et al., 2013). The treatment during dry period showed a great success with significant elimination of $S$. agalactiae and mastitis (Kashif et al., 2016). Application of dry cow therapy for 2 weeks revealed marked decrease in the number of cases of clinical mastitis caused by $S$. dysgalactiae and S. uberis (Hassan et al., 1999).

A study was conducted among 106 dry cows periods for measuring the efficiency of three different treatment protocols regarding the elimination and prevention of S. aureus intramammary infection. At drying off, norfloxacin nicotinate was given subcutaneously to 44 cows at $10 \mathrm{mg} / \mathrm{kg}$, oxytetracycline $\mathrm{Hcl}$ was administered intramuscularly to 18 cows at $20 \mathrm{mg} / \mathrm{kg}, 500 \mathrm{mg}$ cephapirin benzathine were infused into each udder quarter of 21 cows. Results suggested that systemic dry cow therapy using norfloxacin nicotinate, which possesses large distribution volume, long half-life and is highly active against the $S$. aureus, was more effective than other treatments (Soback et al., 1990).

\section{Probiotics}

According to the $\mathrm{WHO}$, the probiotics are defined as living microorganisms that when used in sufficient amounts provides health benefit to the host. The most commonly used organisms are the genera of Lactobacillus and Bifidobacterium owing to their safe administration in dairy industry and their natural existence in the human intestine .The use of two nisins for prevention or treatment of bovine mastitis have been evaluated; the nisin $\mathrm{A}$, origin Ambicin $\mathrm{N}$ which has germicidal properties against pathogens of mastitis (S. aureus, S. agalactiae, $S$ uberis, K. pneumoniae and E. coli), and the nisin Z, origin nisin Z SilverElephant with germicidal activity against pathogens of mastitis (Bogni $\boldsymbol{e t}$ al. 2011). A new bacteriocin produced by Lactococcus lactis species proved high effect against a variety of Gram positive bacteria (Klostermann et al., 2008), that gives protection against infection with Streptococcus dysgalactiae and Staphylococcus aureus during the dry period in cows (Ryan et al., 1999). Furthermore, lactin NK34 (which is partially purified from lacticin NK34) has shown in vivo preventive and therapeutic effects on mouse infection model utilizing pathogens causing mastitis (Espeche et al., 2009; Bogni et al., 2011).

\section{Herbal treatment}

Medicinal plants have many advantages as they are natural, safe, effective and economical alternative treatment for mastitis. Minthostachys verticillata is one of the most commonly used plants in folk medicine. It is an aromatic and autochthonous medicinal plant, native of Cordoba province, Argentina. Minthostachys verticillata has numerous ethnobotanical therapeutic properties (Schmidt Lebuhn, 2008). Montironi et al. (2016) reported that the essential oil and limonene of Minthostachys verticillata inhibited the growth of Streptococcus uberis, Escherichia coli and Enterococcus faecium which cause bovine mastitis. Moreover, Cerioli et al. (2018) reported that the essential oil and limonene of Minthostachys verticillata have antibacterial effect against the pathogens of mastitis such as Staphylococcus aureus, and Coagulase-Negative Staphylococci (CNS) using disk diffusion test. In Egypt, Zeedan et al. (2014) evaluated the antibacterial activity of some Sinai medicinal plant extracts (Artemisia herb-alba and Jasoniamontana) against bacteria isolated from bovine mastitis. They 
reported that the acetone extract of Jasoniamontana plant revealed high antibacterial activity against $S$. agalactiae, E. coli, Staphylococcus aureus, Klebsiella species and coagulase-negative Staphylococci. They added that $J$ Montana and $A$. herb alba plants have antimicrobial effects compared with conventional antibiotics which used in treatment of bovine mastitis.

\section{Silver nano-particles treatment}

The application of silver nanoparticles (AgNPs) have been widely practiced in a variety of fields such as antibacterial agents, chemotherapy, biomarkers, cell labels, and drug delivery systems for the treatment of different diseases, since AgNPs act as carrier for many molecules (Gurunathan, 2015; Yah and Simate, 2015). Multi-drug resistance (MDR) has become an emerging threat in the therapy of bacterial infections; this problem is assigned to the extensive use of broad-spectrum antibiotics (Saini et al., 2012) which leads to massive economic losses in dairy farms. Therefore, there is a critical need for the development of alternative antimicrobial agents such as silver nanoparticles which provide mean to overcome MDR. Yuan et al. (2017) studied the effect of synthesized AgNPs against two multidrug resistance pathogenic bacteria; $P$. aeruginosa and $S$ aureus which were isolated from milk samples. The minimum inhibitory concentrations (MICs) of AgNPs against P. aeruginosa and S. aureus were recorded to be 1 and $2 \mu \mathrm{g} / \mathrm{mL}$, respectively. They suggested that silver nanoparticles have antimicrobial effects in a dose and time dependent manner. They confirmed that the antimicrobial effect of silver nanoparticles is attributed to many mechanisms as the production of reactive oxygen species, malondialdehyde which would compromise the structure and morphology of the bacterial cell. Also, AgNPs cause leakage of proteins and sugars from bacterial cells which alter the osmotic pressure of the cells. They recorded that bacterial treatment with AgNPs had significantly reduced the lactate dehydrogenase activity and reduced adenosine triphosphate levels compared to the control non treated bacteria. Additionally, silver nanoparticles-treated bacteria showed decreased regulated expression of glutathione, up regulation of glutathione $\mathrm{S}$ transferase and down regulation of both superoxide dismutase and catalase Consequently, nanoparticles can be used as antimicrobial agents in the Biotechnology and Bio-medical fields. Kaoud and Yosseif (2013) demonstrated the efficacy of intramammary infusion of silver nanoparticles (AgNPs) in treatment of mastitis in buffaloes caused by mixed infection with $E$. coli, Staphylococcus aureus and Streptococcus agalactiae. They found that the cure rate was $60 \%$ against these infectious bacteria.

\section{Stem cells therapy}

Stem cells are those cells that able to regenerate through the replication and differentiating into specific lineages. Stem cells have been recently researched in large scale. Epithelial and myoepithelial stem cells are considered as the major stem cell types, so they have great therapeutic importance in mammary gland tissue because they can help the development of a vascular network (endothelial and smooth muscle cells) of the mammary gland (Bierla et al., 2012). Capuco $e$ al. (2009) studied the effect of intramammary infusion of xanthosine regarding the population of mammary stem cells in bovine. They concluded that the in vivo treatment with xanthosine can elevate the amount of mammary stem cells. Sharma and Jeong (2009) reported that different kinds of stem cells can be adjusted to reverse the post mastitis fibrosis in bovine udder and return the milk production. They added that stem cells can potentially regenerate damaged tissues by differentiation into epithelial, myoepithelial and or cuboidal/columnar cells in the udder.

\section{Animal vaccination}

Animal vaccinations are important tools for protection against many infectious bacterial diseases that affecting bovine milk.

\section{Vaccination against Staphylococcus aureus and Streptococcus agalactiae}

There are many types of vaccines prepared against Staphylococcus aureus (Middleton, 2008; Middleton et al., 2009) such as whole microorganism vaccines (Leitner et $\boldsymbol{a l}$., 2003a), DNA vaccine encoding clumping factor A (Nour El-Din et al., 2006), live attenuated aroA gene of $S$. aureus (Buzzola et al., 2006), capsular polysaccharide (CPS) protein conjugate vaccines (Mamo $\boldsymbol{e}$ $\boldsymbol{a l}$., 1994) and recombinant $S$. aureus mutated enterotoxin type $C$ (Chang $\boldsymbol{e t}$ al., 2008). Somato-Staph/ Lysigin vaccine is a commercial vaccine which has been used in the USA for 40 years (Ruegg, 2005). Somato-Staph/ Lysigin vaccine is a polyvalent whole cell vaccine contains five phage types of cultures lysates. It decreases the severity of bovine mastitis and the somatic cell count in bovine milk, although it can't protect cows from new infections (Nickerson, 1999). Another vaccine against $S$. aureus is MASTIVAC-1 which is composed of three various field $S$. aureus strains, it showed significant increase in serum immunoglobulin, reduce milk SCC and also showed promising results in the field trials (Leitner et al., 2003b). Meanwhile, it can't protect cows from new infections. Another trivalent vaccine, consists of $S$. aureus serotype 5, 8 and 336 lysates, was recorded to enhance the $\mathrm{IgG} 1$ and $\mathrm{IgG} 2$ release in the serum of heifers (Lee et al., 2005). Nevertheless, the effectiveness of this vaccine against intramammary infections caused by $S$. aureus was not studied. Nour El-Din et al. (2006) found that the DNA vaccine encoding clumping factor A of $S$. aureus produced high antibody titer in vaccinated cows. Pellegrino et al. (2010) evaluated the efficacy of avirulent mutant RC122 S. aureus strain in dairy heifers. They recorded high significant levels of $\mathrm{IgG}$ in the milk and blood of the vaccinated heifers. Prenafeta et al. (2010) reported that the immunization of twelve gestating dairy cows with a vaccine consists of extracellular component from $S$. aureus leads to a marked reduction on the growth of $S$. aureus in the mammary gland. Xu et al. (2011) evaluated the efficiency of a recombinant vaccine consisted of $S$. aureus clumping factor A and surface immunogenic protein of $S$. agalactiae. The results showed significant increase in the serum IgG1 antibody titre in experimentally immunized mice. Moreover, the vaccine protected the mammary gland tissue against $S$. agalactiae and $S$. aureus infection. Maira-Litrán et al. (2012) studied the efficacy of a conjugate vaccine composed of Staphylococcus aureus poly-N-acetyl-glucosamine and clumping factor A in a murine bacteraemia model. They reported that it is a highly immunogenic vaccine. Ghobrial et al. (2018) evaluated the efficacy of vaccine and antibiotic for control of mastitis caused by $S$. aureus in dairy cattle in Egypt. They found that the combination of $S$. aureus bacterin (Lysigin) with extended antibiotic (Marbocyl 10\%) was successfully effective in the elimination of $53.8 \%$ of bovine mastitis caused by $S$. aureus.

\section{Vaccination against coliform bacteria}

Dosogne et al. (2002) developed a vaccine against coliform mastitis using E. coli heterogeneous oligosaccharide antigens, where these vaccines were used during the dry period in order to protect cows against mastitis in the following lactations. They recorded that these vaccines decreased the clinical severity of the infection in the beginning, however, their effect faded progressively. Mastiguard and J Vac are commercially available vaccines against coliform mastitis. Startvac (Hipra) is a novel vaccine which offers protection against coliforms, coagulase-negative staphylococci and S. aureus (Ruegg, 2005; Bradley et al., 2015; Freick et al., 2016). J-5 Bacterin is another vaccine available against coliform mastitis which is composed of the $\mathrm{J} 5$ mutant strain of $E$. coli. This vaccine showed significant decrease in the cases of clinical mastitis in the vaccinated cows under field conditions. However, vaccination cannot protect against developing of recent infections in the vaccinated cows (González et al., 1989; Hogan et al., 1992 b; Wilson et al., 2009).

\section{Vaccination against Mycoplasma bovis}

There are no available commercial licensed vaccines for Mycoplasma bovis for use in young dairy calves. There are several whole bacterin based vaccines including autogenous preparations which are available only in USA (Nicholas $\boldsymbol{e t}$ al., 2009). A field study was conducted to detect the effect of a common commercial Mycoplasma bovis vaccine which is used in USA for the prevention of

Mycoplasma bovis-associated infection in calves (Maunsell et al., 2009). It was reported that this vaccine was not effective for the prevention of Mycoplasma bovis-associated infection in young dairy animals. Vaccines against M. bovis have afforded partial protection from respiratory disease (Stott et al., 1987). A vaccine prepared with formalin inactivated strains of Mycoplasma bovis and Mannheimia haemolytica decreased both losses from pneumonia and the cost of therapy in the recently introduced feedlot calves (Urbaneck et al., 2000). An inactivated vaccine containing Saponin killed $M$. bovis was found to be immunogenic, safe and protective against an experimental challenge with virulen Mycoplasma bovis, but the time of protection with this type of vaccine is very short (Nicholas $\boldsymbol{e t}$ al., 2002). Balb/c mice were intramuscularly vaccinated with the obtained fraction candidate from Mycoplasma bovis either alone or combined with Freund's incomplete adjuvant (FIA). A significant level of specific antiMycoplasma bovis IgG antibody titers was found in the sera of vaccinated mice with the fraction candidate alone or combined with Freund's incomplete adjuvant, especially after the third vaccination (Ismael et al., 2016).

\section{Vaccination against Mycobacterium tuberculosis}

The attenuated Mycobacterium tuberculosis- bovis strain BCG vaccine has been evaluated for use in cattle (Buddie $\boldsymbol{e t}$ al., 1995), it was used in vaccination of cattle in developing countries that don't have fund for a test and slaughter strategy. Vaccination has not generally been seriously considered in test and slaughter programs because of the cross-reaction with tuberculin test that is used for disease diagnosis (Cousins, 2001).

\section{Vaccination against brucellosis}

Vaccination is widely practiced strategy to avoid the spreading of infection with brucellosis. The most commonly used vaccines in practice are B. abortus strain 
19 and RB 51 vaccines (Frolich et al., 2002, Martins et al., 2009), both are live attenuated vaccines derived from B. abortus (Moriyon et al., 2004). S19 vaccine was found to be superior to RB51 regarding long term immunity in young calves (Dorneles et al., 2015; Miranda et al., 2015). RB51 vaccine does not interfere with serological diagnosis and therefore help in differentiation between vaccinated and infected animals (Sanz, et al., 2010; Barbosa et al., 2017) Moreover, Godfroid et al. (2011) recommended the vaccination of young female calves at age ranged from 3 to 12 months with S19 vaccine; on the other hand this vaccine has limitations as it can induce abortion in pregnant cattle. Yang et al. (2013) tested the efficacy of the DNA vaccines and concluded that they are very promising compared with S19 and RB51 vaccines, nonetheless they need boosters doses to obtain the desired immunity (Gomez et al., 2018). To sum up, there is no currently available effective and relatively safe vaccine that can protect against brucellosis for long term.

\section{CONCLUSION}

Control of bacterial infectious diseases in bovine milk is done through application of preventive measures, animal vaccination and proper treatment of diseased cows by using suitable antibiotics guided with antibiotic sensitivity tests. In addition to, alternative treatments such as probiotics, herbal treatment, silver nanoparticles and stem cell therapy which offer reliable and effective methods to overcome multidrug resistance (MDR). Following proper hygienic practices concerning animal husbandry and handling is the key role in bacterial disease prevention. Promoting animal welfare through proper balanced animal nutrition provides a great help for boosting the animals immune response against bacterial infections. Following vaccination program provides protection of dairy farm animals by preventing or reducing bacterial diseases which in turn can helps safeguard dairy industry. Meticulous inspection of the consistency and color of milk will increase the chances of early diagnosis. Monitoring animal udder health on regular basis by using conventional field tests since they provide great help for screening the health status of the herd in intensive production dairy farms assigned to their low cost and convenience. Implementing proper handling practices during milking is mandatory in order to produce safe and suitable milk and milk products. Creating campaigns to increase the public awareness of the risks of consuming raw milk, moreover it is necessary to encourage the consumers to shift towards using pasteurized milk. Animal vaccinations are important tools for protection against many infectious bacterial diseases that affecting bovine milk.

\section{REFERENCES}

Abdelhafez, S.M., Yassin, M.H. \& Gomma, A.M. (2009). The use of latex agglutination test as a rapid method for detection of antibodies to Mycoplasma bovis in comparsion with ELISA. Assiut Vet. Med. J. 55, 1-8.

Abdelhameed, F. \& Sharaf, E.M. (2009). Bacteriological studies on mastitis of dairy animals with special reference to Mycoplasma infection in Menofia and Kaluobia Governorates, Egypt. Assiut Vet. Med. J. 55, 1-20.

Abou-Zeina, H.A.A., Ghazy, A.A., El-Bayoumy, M.K., Dorgham, S.M., Khairy, E.A. \& Twfik, H.I. (2013). Effects of dietary antioxidants supplementation on cellular immune response and evaluation of their antimicrobial activity against some enteric pathogens in goats. Global Veterinaria. 11, 145-154.

Ahmed, A.M. \& Shimamoto, T. (2011). Molecular characterization of antimicrobial resistance in Gram negative bacteria isolated from bovine mastitis in Egypt. Microbiol. Immunol. 55, 318- 327. http://dx.doi.org.10.1111/j.1348$\underline{0421.2011 .00323}$

Ammar, A.M.A., El-Shafii, S.S.A., Amo, A.E \& El-Dayim, Z.A.A. (2016) Detection of Multidrug Resistance Genes in Pseudomonas aeruginosa isolated from Bovine Mastitic Milk. J. Dairy Vet. Anim. Res. 3 , 00071.http;//dx.doi.org/10.15406/jdvar.2016.03.00071

Babra, C., Tiwari, J.G., Pier, G., Thein, T.H., Sunagar, R., Sundareshan, S., Isioor, S., Hegde, N.R., De wet, S., Deighton, M., Gibson, J., Costantino, P. Wetherall, J. \& Mukkur, T. (2013). The persistence of biofilm-associated antibiotic resistance of Staphylococcus aureus isolated from clinical bovine mastitis cases in Australia. Folia Microbiol. 58, 469-74. http://dx.doi.org/10.1007/s12223-013-0232-z

Barbosa, A.A., Figueiredo, S.C.A., Palhao, P.M., Viana, M.H.J. \& Fernandes, C.A.C. (2017). Safety of vaccination against brucellosis with the rough strain in pregnant cattle. Trop. Anim. Health Prod., 49, 17791781.http://dx.doi.org/10.1007/s11250-017-1361-1

Berry, E.A. \& Hillerton, J.E. ( 2002). The Effect of Selective Dry Cow Treatment on New Intramammary Infections. J. of Dairy Sci., 85, 112 121.https://dx.doi.org/10.3168/jds.S0022-0302(02)74059-9

Bhanurekha ,V., Gunaseelan, L., Subramanlan, A. \& Yale, G. (2013). A study on bovine brucellosis in an organized dairy farm. Vet. World., 6, 681 685.http://.dx.doi.org/10.14202/vetworld.2013.681-685

Bierla, J.B., Osinska, E. \& Motyl, T. (2012). Bovine mammary stem cells studies-current status a review. Anim. Sci. Pap. Rep., 30, 195-204.

Bogni, C., Odierno, L., Raspanti, C., Giraudo, J. \& Larriestra, A. (2011). War against Mastitis: Current Concepts on Controlling Bovine Mastitis Pathogens. In:
Science against Microbial Pathogens: In: Science against Microbial pathogens: Communicating Current Research and Technological Advances, Mendez-Vilas, A. (Ed.). World Scientific, Singapore, ISBN-13: 978981 4354868, pp: 483-494. Bradley, A.J., Breen, J.E, Payne, B., White, V. \& Green, M.J. (2015). An investigation of the efficacy of a polyvalent mastitis vaccine using different vaccination regimens under field conditions in the United Kingdom. J. Dairy Sci., 98, 1706-1720.https://dx.doi.org/10.3168/jds.2014-8332

Buddie, B.M., De lise, G.W., Pfeffer, A. \& Aldwell, F.E. (1995). Immunological responses and protection against Mycobacterium bovis in calves vaccinated with a low dose of BCG. Vaccine, 13, 1123-1130.https://doi.org/10.1016/0264410X(94)00055-R

Buzzola, F.R., Barbagelata, M.S., Caccuri, R.L. \& Sordelli, D.O. (2006). Attenuation and persistence of and ability to induce protective immunity to a Staphylococcus aureus aroA mutant in mice. Infect. Immun., 74, 34983506.http://dx.doi.org/10.1128/IAI.01507-05

Bytyqi, H., Zaugg, U., Sherifi, K., Hamidi, A., Gjonbalaj, M., Muji, S. \& Mehmeti, H. (2010). Influence of management and physiological factors on somatic cell count in raw cow milk in Kosova. Vet. Archiv., 80, 173-183.

Calzolari, A., Giraudo, J.A., Rampone, H., Odierno, L. \& Giraudo (1997). Field trials of a vaccine against bovine mastitis. 2. Evaluation in two commercial dairy herds. J. Dairy Sci., 80, 854- 858.http://dx.doi.org/10.3168/jds.S00220302(97)76006-5

Camussone, C.M., Veaute, C.M., Porporatto, C., Morein, B., Marcipar, I.S. \& Calvinho, L.F. (2013). Immune response of heifers against Staphylococcus aureus CP5 whole cell vaccine formulated with ISCOMATRIX adjuvant. $J$ Dairy Res., 80, 72-80. http://dx.doi.org./10.1017/S0022029912000593

Capuco, A.V., Evock-Clover, C.M. \& Minuti, A. (2009). In vivo expansion of the mammary stem/progenitor cell population by xanthosine infusion. Exp. Biol. Med., 234, 475- 482.http://dx.doi.org./10.3168/jds.S0022-0302(97)76006-5

Cerioli, M.F., Moliva, M.V., Cariddi, L.N. \& Reinoso, E.B. (2018). Effect of the Essential Oil of Minthostachys verticillata (Griseb.) Epling and Limonene on Biofilm Production in Pathogens Causing Bovine Mastitis. Front. Vet.Sci., 5:146.https://doi.org/10.3389/fvets.2018.00146

Chamberlain, A.T. \& Wilkenson, J.M. (1996). Feeding the dairy cow. Chalcombe Publications, 90-91.

Chang, B.S, Moon, J.S, Kang, H.M., Kim, Y.I., Leh, K., Kim, J.D., Lee, B.S., Koo, H.C \& Park, Y.H. (2008). Protective effects of recombinant Staphylococcal enterotoxin Type $\mathrm{C}$ mutant vaccine against experimental bovine infection by a strain of Staphylococcus aureus isolated from subclinical mastitis in dairy cattle. Vaccine., 26, 2081-2091. https://doi.org/10.1016/j.vaccine.2008.02.043

Couins, D.V. (2001). Mycobacterium bovis infection and control in domestic livestock. Rev. sci. tech. Off. int. Epiz. 20, 71-85.

Dorneies, E.M., Lima, K.G., Teixeira-Caryalho, A., Araujo, S.M., Martins-Filho, A.O., Sriranganathan, N., Alqublan, H., Heinemann, B.M. \& Lage, P.A. (2015) Immune response of calves vaccinated with Brucella abortus S19 or RB51 and revaccinated with RB51. PLOS ONE, e0136696.https://doi.org/10.1371/journal.pone.0136696

Dosogne, H., Vangroenweghe, F. \& Burvenich, C. (2002). Potential mechanism of action of $\mathrm{J} 5$ vaccine in protection against severe bovine coliform mastitis. Vet. Res. 33, 1 - 12.https://doi.org/10.1051/vetres:2001001

Eissa, S.I., Hassan, A.M., Hashem Y.M. \& Shaker M.M. (2012). Comparative Molecular Study of Mycoplasma Bovis Isolates from Egyptian Buffaloes and Cows Suffered from Mastitis. Europ. J.of Biol. Sci. 4, 114120.https://doi.org/10.5829/idosi.ejbs.2012.4.4.6668

Elbably, M.A., Emeash, H.H. \& Asmaa, N.M. (2013). Risk factors associated with mastitis occurrence in dairy herds in Beni-Suef Governorate. World's Vet. J., 3, 05-10.

Enany, M.E., EL-Attar, A.A., Khafagy, A.A.R. \& EL-Gammal, A.M. (2007) Bacterial and mycotic causes of subclinical bovine mastitis. SCVMJ, 2, 107-114. Erskine, R.J., Eberhart, R.J., Grasso, P.J. \& Scholz, R.W. (1989). Induction of Escherichia coli mastitis in cows fed selenium-deficient or seleniumsupplemented diets. Am. J. Vet. Res. 50, 2093- 2100.

Espeche, M.C., Otero, M.C., Sesma, F. \& Nader-Macias, M.E.F. (2009) Screening of surface properties and antagonistic substances production by lactic acid bacteria isolated from the mammary gland of healthy and mastitic cows. Vet. Microbiol., $135, \quad 346 \quad-357$ https://doi.org/10.1016/j.vetmic.2008.09.078

Finch, J.M., Winter, A., Walton, A.W. \& Leigh, J.A. (1997). Further studies on the efficacy of a live vaccine against mastitis caused by Streptococcus uberis Vaccine, 15, 1138-1143. https://doi.org/10.1016/S0264-410X(96)00307-6

Food and Drug Administration (FDA) (2011). Available at (http://www.fda.gov/AnimalVeterinary). Accessed June 10.

Fountaine, M.C., Peres-Casal, J., Song, X.M., Shelford, J., Wilson, P.J. \& Potter, A.A. (2002). Immunisation of dairy cattle with recombinant Streptococcus uberis GapC or a chimeric CAMP antigen confers protection against heterologous bacterial challenge. Vaccine, 20, 2278- 2286. https://doi.org/10.1016/S0264410X(02)00114-7

Freick, M., Frank, Y., Steinert, K., Hamedy, A., Passarge, O. \& Sobiraj, A (2016). Mastitis vaccination using a commercial polyvalent vaccine or a herdspecific Staphylococcus aureus vaccine. Results of a controlled field trial on a 
dairy farm. Tierarztl. Prax. 4, 219-229. http://dx.doi.org/10.15653/TPG-150912 Frolich, K., Thiede, S., Kozikowski, T. \& Jakob, W. (2002). A review of mutual transmission of important infectious diseases between livestock and wildlife in Europe. Ann. N. Y. Acad. Sci. 969, 4-13. https://doi.org/10.1111/j.1749 6632.2002.tb04343.x

Ghazy, A.A., Ahmed, W.M., Mahmoud, M.A. \& Ahmed, L.A. (2007a) Prevalence of Infectious Bovine Rhinotracheitis and Bovine Viral Diarrhoea Viruses in Female Buffaloes with Reporoductive Disorders and Parasitic Infections. International Journal of Dairy Science, 2 (4), pp. 339-347. http://doi.org/10.3923/ijds.2007.339.347

Ghazy, A.A., Ghazi, Y.A., Mahmoud, K.G.M. \& Farghaly, A.A. (2007b) Preliminary study on chromosomal aberrations related to brucellosis in buffaloes and bovine tuberculosis in dairy cattle. International Journal of Dairy Science, 2 (4), pp. 302-311.

Ghobrial, R.F., El Beskawy, M.A., Diasty, M.M., Farag, V.M. \& Eissa, M. (2018). Field trail to evaluate a vaccine and antibiotic for control of Staph. aureus mastitis in dairy cattle in Egypt. AJVS, 56, 88-94.

Gilmour, A. \& Harvey, J. (1997). Staphylococci in milk and milk products. Society for Applied Bacteriology Symposium Series, 19, 147S- 166S

Godfroid, J., Scholz, C.H., Barbier, T., Nicolas, C., Wattiau, P., Fretin, D., Whatmore, M.A., Cloeckaert, A., Blasco, M.J. \& Moriyon, I. (2011). Brucellosis at the animal/ ecosystem/ human interface at the beginning of the $21^{\text {st. }}$ century. Prev. Vet. Med. 102, 118-131. https://doi.org/10.1016/j.prevetmed.2011.04.007 Gomez, L., Alvarez, F., Betancur, D. \&, Onate, A. (2018). Brucellosis vaccines based on the open reading frames from genomic island 3 of Brucella abortus. Vaccine, 36, 2928-2936. https://doi.org/10.1016/j.vaccine.2018.04.014 Gonzalez, R.N., Cullor, J.S., Jasper, D.E., Farver, T.B. \& Bushnell, R.B. (1989). Prevention of clinical coliform mastitis in dairy cows by a mutant Escherichia coli vaccine. Can. J. Vet. Res. 53, 301- 305.

Grueta , P., Maincentb, P., Berthelotc, X.\& Kaltsatosa ,V. (2001). Bovine mastitis and intramammary drug delivery: review and perspectives. Adv. Drug Deliv. Rev. 50, 245- 259. https://doi.org/10.1016/S0169-409X(01)00160-0

Gurunathan, S. (2015). Biologically synthesized silver nanoparticles enhances antibiotic activity against Gram-negative bacteria. J. Ind. Eng. Chem. 29, 217 226. https://doi.org/10.1016/j.jiec.2015.04.005

Hakim, A.S, Tantawy, N. A., Syame, S.M., Sedky, D., Hedia, R. H. \& Elshafaie, M.A. (2017). Livestock- Associated Staphylococcus aureus pathogenicity with regards to resistance and virulence Genomics and Accessory Gene regulator locus proteomics. Asian J. of epidemiol.10, 89-100. http://doi.org/10.3923/aje.2017.89.100

Halasa, T., Huijps, K., Osteras, O. \& Hogeveen, H. (2007). Economic effects of bovine mastitis and mastitis management: A review. Vet. Quart. 29, 3 .https://doi.org/10.1080/01652176.2007.9695224

Harmon, R.J. (1994). Physiology of mastitis and factors affecting somatic cell counts. J. Dairy. Sci. 77, 2103- 2112. https://doi.org/10.3168/jds.S0022$\underline{0302(94) 77153-8}$

Hassan, W.H., Hatem, M.E., Elnwary, H.A. \& Sediek, S.H. (2016) Characterization of antimicrobial resistant bacterial pathogens recovered from cases of bovine mastitis with special reference to Staphylococcus aureus. J. of Vet. Med. Res., 23, 101-111.

Hassan, Z., Daniel, R.C., O’Boyle, D., Frost, A.J. (1999). Effects of dry cow intramammary therapy on quarter

Rec., 145, 635- 639. http://dx.doi.org/10.1136/vr.145.22.635

Hassanain, N.A., Hassanain, M.A., Soliman, Y.A. ,Ghazy, A.A. \& Ghazyi Y.A (2009). Bovine tuberculosis in a dairy cattle farm as a threat to public health. Afr. J. Microbiol. Res. 3, 446-450.

Hogan, J.S., Weiss, W.P., Todhunter, D.A., Smith, K.L. \& Schoenberger, P.S (1992a). Bovine neutrophil responses to parenteral vitamin E. J. Dairy Sci., 75 399-405. https://doi.org/10.3168/jds.S0022-0302(92)77775-3

Hogan, J.S., Weiss, W.P., Todhunter, D.A., Smith, K.L. \& Schoenberger, P.S (1992b). Efficacy of an Escherichia coli J5 mastitis vaccine in an experimental challenge trial. J. Dairy Sci., 75, 415-422. https://doi.org/10.3168/jds.S00220302(92)77777-7

Huchzermyer, H.F.K.A., Bruckner, G.K., Van Heerden, A., Kleeberg, H.H., van Rensburg , I.B.J., Koen, P. \& Loveday, R.K. (1994). Tuberculosis. In Infectious diseases of livestock with special reference to Southern Africa (JAW. Coetzer, G.R. Thomson \& R.C. Tustin, eds). Oxford University Press, Cape Town, 1425 1443.

Hussein, H.A., Abd El-Razik, K.A., Gomaa, A.M., Elbayoumy, M.K. Abdelrahman, K.A.\& Hosein, H.I. (2018). Milk amyloid A as a biomarker for diagnosis of subclinical mastitis in cattle. Vet. World, 11, 34- 41. http://dx.doi.org/10.14202/vetworld.2018.34-41

Ismael, A.B., Hassan, M.Y., Mostafa, S.A., Nassan, M.A. \& Mohamed, E. H. (2016). Development of a Second-Generation Vaccine against Mycoplasmosis: Preparation of a Fraction Candidate from Mycoplasma bovisand its Evaluation as a Vaccine. Glob. Vet., 16, 137-144.

Ismail, Z.B. (2017). Mastitis vaccines in dairy cows: Recent developments and recommendations of application. Vet. World, 10, 1057-1062. http://dx.doi.org/10.14202/vetworld.2017.1057-1062

Janosi, S.Z. \& Huszenicza, G. (2001). The use of the dry cow therapy in the control of bovine mastitis. Vet. Med Czech., 46, 55-60

Kaoud, H.A., Yosseif, S. (2013). Innovative method for the treatment of mastitis in dairy animals. J. of Vet. Sci. Photon., 114, 240-244.

Kashif, M., Rizwan, M., Ali, M., Ahmad, T. \& Durrani, A.Z. (2016). Control of Mastitis through dry cow therapy. Veterinaria, 2, 13-16.

Khan, M. Z. \& Zahoor, M. (2018). An Overview of Brucellosis in Cattle and Humans, and its Serological and Molecular Diagnosis in Control Strategies. Trop. Med. Infect. Dis. 3, 65 https://doi.org/10.3390/tropicalmed3020065

Klostermann, K., Crispie, F., Flynn, J., Ross, R.P., Hill, C. \& Meaney, W., (2008). Intramammary infusion of alive culture of Lactococcus lactis for treatment of bovine mastitis: comparison with antibiotic treatment in field trials. J. Dairy. Res. 75, 365-373.

Kumar, A., Rahal, A., Dwivedi, S.K. \& Gupta, M.K. (2010). Bacterial prevalence and antibiotic resistance profile from bovine mastitis in Mathura, India. Egypt. J. Dairy Sci., 38, 31-34

Lee, J.W., O'brien, C.N., Guidry, A.J., Paape, M.J., Shafer-Weaver, K.A. \& Zhao, X. (2005). Effect of a trivalent vaccine against Staphylococcus aureus mastitis lymphocyte subpopulations, antibody production and neutrophil phagocytosis. Can. J. Vet. Res., 69, 11-18.

Leitner, G., Lubachevsky, E., Glikman, E., Winkler, M. \& Saran, A. (2003a). Development of a Staphylococcus aureus vaccine against mastitis in dairy cows. I. Challenge trials. Vet. Immunol.Immunopathol., 93, 31- 38.

Leitner, G., Yadlin, N., Lubashevsky, E., Ezra, E., Glickman, A., Chaffer, M. Winkler, M., Saran, A. \& Trainin, Z., (2003b). Development of a Staphylococcus aureus vaccine against mastitis in dairy cows. II. Field trial. Vet. Immunol. Immunopathol., 4, 153-158.

Lejeune, J. T. \& Schultz, P. J. R. (2009). Food safety unpasteurized Milk: A Continued Public Health Threat. Clin. Infect. Dis., 48, 93 100.https://doi.org/10.1086/595007

Madut, N.A. \& Gadir, A.A. (2011). Susceptibility of Corynebacterum spp. responsible for bovine mastits against commonly used antibiotics in Kuku dairy farms, Sudan. J. Cell Anim. Biol., 5, 6- 10.

Mahmoud, A.A., Khadr, A.M., Elshemy, T.M., Hamoda, H.A., Mohaed, I., Ismail, M.I. (2015). Some Studies on E. coli Mastitis in Cattle and Buffaloes. Alexandria J. Vet. Sci., 45, 105- 112. http://doi.org/10.5455/ajvs.178113

Maira-Litran, T., Bentanor, L.V., Bozkurt-Guzel, C., O’Malley, J.M. \& CywesBentley, C. (2012). Synthesis and evaluation of a conjugate vaccine composed of Staphylococcus aureus poly-N-acetyl-glucosamine and clumping factor A. PLoS One, 7: e43813. https://doi.org/10.1371/journal.pone.0043813

Mamo, W., Jonsson, P., Flock, J.I., Lindberg, M. \& Müller, H.P. (1994) Vaccination against Staphylococcus aureus mastitis: immunological response of mice vaccinated with fibronectin- binding protein (FnBP-A) to challenge with $S$. aureus. Vaccine, 12, 988- 992. https://doi.org/10.1016/0264-410X(94)90333-6

Martins, H., Garin-Bastuji, B., Lima, F., Flor, L., Pina Fonseca, A. \& Boinas, F. (2009). Eradication of bovine brucellosis in the Azores, Portugal-Outcome of a 5-year programme (2002- 2007) based on test-and-slaughter and RB51 $\begin{array}{llll}\text { vaccination. } & \text { Prev. } & \text { Vet. } & \text { Med. }\end{array}$ https://doi.org/10.1016/j.prevetmed.2009.04.002

Maunsell, F.P., Donovanb, G.A., Risco C. \& Brown, M.B. (2009). Field evaluation of a Mycoplasma bovis bacterin in young dairy calves. Vaccine, 27 2781- 2788. https://doi.org/10.1016/j.vaccine.2009.02.100

Middleton, J.R. (2008). Staphylococcus aureus antigens and challenges in vaccine development. Expert. Rev. Vaccines, 7, 805- 815 https://doi.org/10.1586/14760584.7.6.805

Middleton, J.R, Luby, C.D. \& Adams, S.D. (2009). Efficacy of vaccination against Staphylococcal mastitis: A review and new data. Vet. Microbiol., 2,192198. https://doi.org/10.1016/j.vetmic.2008.09.053

Miranda, K.L., Dorneles, M.E., Pauletti, B.R., Poester, P.F. \& Lage, P.A. (2015) Brucella abortus S19 and RB51 vaccine immunogenicity test: Evaluation of three mice (BALB/c, Swiss and CD-1) and two challenge strains (544 and 2308). Vaccine., 33, 507-511. https://doi.org/10.1016/j.vaccine.2014.11.056

Montironi, I.D., Cariddi, L.N. \& Reinoso, E.B. (2016). Evaluation of the antimicrobial efficacy of Minthostachysverticillata essential oil and limonene one of its major components, against Streptococcus uberis strains isolated from bovine mastitis. Rev. Argent. Microbiol., 48, 210-216. https://doi.org/10.1016/j.ram.2016.04.005

Moriyon, I., Grillo, J.M., Monreal, D., Gonzalez, D., Marin, C., Lopez-Goni, I., Mainar-Jaime, C.R., Moreno, E. \& Blasco, M.J. (2004). Rough vaccines in animal brucellosis: Structural and genetic basis and present status. Vet. Res. 35, 1-38. https://doi.org/10.1051/vetres:2003037

Mosaad, A.A., Abdel-Hamed, A.S., Fathalla, S.I., Ghazy, A.A., Elballal, S. Elbagory, A., Mahboub, H., Gaafar, K., Elgayar, K.E., Mohamed, A.S., Amin, A.I., Akella M.A. \& Abdelrahman, H.A. (2012). Sensitive and Specific Diagnostic Assay for Detection of Tuberculosis in Cattle. Global Veterinaria, $8(6), 555-564$

Nicholas, R.A.J., Ayling R.D. \& McAuliffe, L. (2009). Vaccines for Mycoplasma diseases in animals and man. J. of Comp. Pathol., 140, 8596.https://doi.org/10.1016/j.jcpa.2008.08.004

Nicholas, R.A.J., Ayling, R.D. \& Stipkovits, L. (2002). An experimental vaccine 
for calf pneumonia caused by Mycoplasma bovis: clinical, cultural, serological and pathological findings. Vaccine, 20, 3569 3575.https://doi.org/10.1016/S0264 410X $(02) 00340-7$

Nickerson, S.C. (1999). Role of vaccination and treatment programs. In Proceedings of 38th Annual Meeting National Mastitis Council, Inc. Madison, WI, 76-85.

Nour El-Din, A.N., Shkreta, L., Talbot, B.G., Diarra, M.S. \& Lacasse, P. ( 2006). DNA immunization of dairy cows with the clumping factor A of Staphylococcus aureus. Vaccine, 24, 1997- 2006. https://doi.org/10.1016/j.vaccine.2005.11.033

Olde Riekerink, R.G.M., Ohnstad I., van Santen B. \& Barkema, H.W. (2012). Effect of an automated dipping and backflushing system on somatic cell counts. J. Dairy Sci., 95, 4931- 4938. https://doi.org/10.3168/jds.20114939

Osman, K.M., El-Enbaawy, M.I., Ezzeldeen, N.A. \& Hussein, H.M.G. (2009) Mastitis in dairy buffalo and cattle in Egypt due to Clostridium perfringens: prevalence, incidence, risk factors and costs. Rev. sci. tech. Off. int. Epiz., 28 975-986.

Owens, W.E., Ray, C.H. Watts, J.L. \& Yancey, R.J., (1997). Comparison of success of antibiotic therapy during lactation and results of antimicrobia susceptibility test for bovine mastitis. J. Dairy Sci., 80, 313-317. https://doi.org/10.3168/jds.S0022-0302(97)75940-X

Paape, M.J., Bannerman, D.D., Zhao, X. \& Lee, J.W. (2003). The bovine neutrophil: Structure and function in blood and milk. Vet. Res., 34, 597-627. https://doi.org/10.1051/vetres:2003024

Pearce, L. E., Smythe, B. W., Crawford, R. A., Oakley, E., Hathaway, S. C.\& Shepherd, J. M. (2012). Pasteurization of milk: The heat inactivation kinetics of milk-borne dairy pathogens under commercial-type conditions of turbulent flow. J. Dairy Sci., 95, 20-35. https://doi.org/10.3168/jds.2011-4556

Pellegrino, M., Giraudo, J., Raspanti, C., Odierno, L. \& Bogni, C. (2010) Efficacy of immunization against bovine mastitis using a Staphylococcus aureus avirulent mutant vaccine. Vaccine, 17, 4523-452 https://doi.org/10.1016/j.vaccine.2010.04.056

Peetroviski, K.R., Trajcev, M. \& Buneski, G. (2006). A review of the factors affecting the costs of bovine mastitis. J. South Afr. Vet. Ass. 77 (5), 52- 60.

Poutrel , B., Stegemann, M.R, Roy, O., Pothier, F., Tilt, N. \& Johnson, M.P. (2008). Evaluation of the efficacy of systemic danofloxacin in the treatment of induced acute Escherichia coli bovine mastitis. J. of dairy Res., 75, 310- 331 https://doi.org/10.1017/S0022029908003348

Prenafeta, A., March, R., Foix, A., Casals, I. \& Costa, L. (2010). Study of the humoral immunological response after vaccination with Staphylococcus aureu biofilm-embedded bacterin in dairy cows: possible role of the exopolysaccharide specific antibody production in the protection from Staphylococcus aureus induced mastitis. Vet. Immunol. Immunopathol., 134, 208- 217 https://doi.org/10.1016/j.vetimm.2009.09.020

Quinn, P.J., Markey, B.K., Leonard, F.C., Fanning, S. \& Maguire, D. (2013) Veterinary Microbiology and Microbial Disease. 2nd ed. Hoboken: Wiley.

Ruegg, R.L. ( 2005). Evaluating the effectiveness of mastitis vaccines. Milk Money, 3, 21 -28.

Ryan, M., Flynn, J., Hill, C., Ross, R. \& Meaney, W. (1999).The natural food grade inhibitor lacticin 3147 can prevent mastitis in nonlactating dairy cows. $J$. Dairy Sci., 82, 2625- 2631. https://doi.org/10.3168/jds.S0022-0302(99)75453-6 Saad, N.M. \& AbdelHameed, K.G. (2012). Detection of Mycoplasma species in raw milk of lactating animals of Assiut and Qena city in Egypt. Vet.World, 2, 80 85. DOI:10.5455/vetworld.2012.80-85

Saini, V., McClure, J.T., Scholl, D.T., DeVries, T.J. \& Barkema, H.W. (2012) Herd-level association between antimicrobial use and antimicrobial resistance in bovine mastitis Staphylococcus aureus isolates on Canadian dairy farms. J. Dairy Sci., 95, 1921- 1929. https://doi.org/10.3168/jds.2011-5065

Sanz, C., Saez, L., Alvarez, J., Cortes, M., Pereira, G., Reyes, A., Rubio, F., Martin, J., Garcia, N. \& Dominguez, L. (2010). Mass vaccination as a complementary tool in the control of a severe outbreak of bovine brucellosis due to Brucella abortus in Extremadura, Spain. Prev. Vet. Med. 97, 119-125. https://doi.org/10.1016/j.prevetmed.2010.08.003

Sayed, R.H., Salamas, S. \& Soliman , R.T. ( 2014). Bacteriological Evaluation of Present Situation of mastitis in dairy cows. Glob. Vet., 13, 690-695 https://doi.org/10.5829/idosi.gv.2014.13.05.86119

Schmidt Lebuhn, A. (2008). Ethnobotany, biochemistry and pharmacology of Minthostachys (Lamiaceae). J. Ethnopharmacol., 118, 343-353. https://doi.org/10.1016/j.jep.2008.05.030

Sharma, N. \& Jeong, D.K. (2009). Stem Cell Research: A Novel Boulevard towards Improved Bovine Mastitis Management. Int. J. Biol. Sci., 9, 818-829. https://dx.doi.org/10.7150/ijbs.6901

Shkreta, L., Talbot, B.G., Diarra, M.S. \& Lacasse, P. (2004). Immune response to a DNA/protein vaccination strategy against Staphylococcus aureus induced mastitis in dairy cows. Vaccine, 23, 114-126. https://doi.org/10.1016/j.vaccine.2004.05.002

Soback, S., Ziv., G, Winkler, M. \& Savan, A. (1990). Systemic Dry Cow Therapy - A Preliminary Report. J.of dairy sci., 73, 661- 666 https://doi.org/10.3168/jds.S0022-0302(90)78717-6

Spears, J.W. \& Weiss, W.P. (2008). Role of antioxidants and trace elements in health and immunity of transition dairy cows. Vet. J., 176, 70- 76 https://doi.org/10.1016/j.tvj1.2007.12.015

Stott , E.J., Thomas L.H., Howard C.J. \& Gourlay, R.N. (1987). Field trial of a quadrivalent vaccine against calf respiratory disease. Vet. Record, 121, 342-7.

Timms, L. (2001). Evaluation of recommended and extended pirlimycin therapy strategies in four high somatic cell count herds. In: Proceedings of Second International Mastitis Milk Quality Symposium. 534- 535 https://doi.org/10.31274/ans_air-180814-37

Underwood, E.J. \& Suttle, N.F. (1999). The Mineral Nutrition of Livestock Underwood EJ and Suttle NF (eds), CABI Publishing, NewYork.

Urbaneck, D., Liebig, F., Forbrig, T. \& Stache, B. (2000). Experiences with herdspecific vaccines against respiratory infections with $M$. bovis in a large feedlot Praktische Tierarzt, 81, 756-63.

Verma, H., Rawat, S., Sharma, N., Jaiswal V. \& Singh R. (2018). Prevalence bacterial etiology and antibiotic susceptibility pattern of bovine mastitis in Meerut. J. Entomol. Zool. Stud., 6, 706-709.

Wareth, G., Melzer, F. Elschner, M. C., Neubauer, H.\& Roesler, U. (2014) Detection of Brucella melitensis in bovine milk and milk products from apparently healthy animals in Egypt by real-time PCR. J. Infect. Dev. Ctries., 8, 1339-1343. https://doi.org/10.3855/jidc.4847

Wilson, D.J., Mallard, B.A., Burton, J.L., Schukken, Y.H. \& Grohn, Y.T. (2009) Association of Escherichia coli J5-specific serum antibody responses with clinical mastitis outcome for $\mathrm{J} 5$ vaccinate and control dairy cattle. Clin. Vaccine Immunol., 16, 209- 217. https://doi.org/ 10.1128/CVI.00324-08

$\mathrm{Xu}, \mathrm{H}$, Hu, C., Gong, R., Chen, Y.\& Ren, N. (2011).Evaluation of a novel chimeric B cell epitope-based vaccine against mastitis induced by either Streptococcus agalactiae or Staphylococcus aureus in mice. Clin. Vaccine Immunol., 18,893- 900. http://doi.org/10.1128/CVI.00066-11

Yah, C.S. \& Simate, G.S. (2015). Nanoparticles as potential new generation broad spectrum antimicrobial agents. Daru. J. of Pharmac. Sci., 23, 43 https://doi.org/10.1186/s40199-015-0125-6

Yang, X., Skyberg, A.J., Cao, L., Clapp, B., Thornburg, T. \& Pascual, W.D. (2013). Progress in Brucella

vaccine development. Front. Biol. 8, 60- 77. https://doi.org/10.1007/s11515 $\underline{012-1196-0}$

Yin, R.C., Li, C., Yang, Z.T., Zhang, Y.J. \& Bai, W.L. (2009). Construction and immunogenicity of a DNA vaccine containing clumping factor A of Staphylococcus aureus and bovine IL18. Vet. Immunol. Immunopathol. 132, 270274. https://doi.org/10.1016/j.vetimm.2009.05.012

Yuan, Y., Peng, Q. \& Gurunathan, S. (2017). Effects of Silver Nanoparticles on Multiple Drug- Resistant Strains of Staphylococcus aureus and Pseudomonas aeruginosa from Mastitis-Infected Goats: An Alternative Approach for

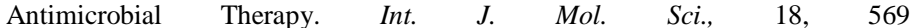
https://doi.org/10.3390/ijms18030569

Zeedan, G.S.G., Abdalhamed, A.M., Abdeen, E., Ottai, M.E. \& Abdel-Shafy, S. (2014). Evaluation of antibacterial effect of some Sinai medicinal plant extracts on bacteria isolated from bovine mastitis. Vet. World, 7, 991- 998 https://doi.org/10.14202/vetworld.2014.991-998. 